\title{
Marketing Promotion Analysis in Medical Checkup Unit at PMI Hospital in 2011
}

\section{Dian Surtikanthi}

Faculty of Public Health, Universitas Indonesia, Depok, Indonesia

\section{Abstract}

The reason why this study has chosen was, the range of consumers in the medical check-up unit at PMI hospital has been decreasing in the last three years. This study is a qualitative study by an in-depth interview with two kinds of informants: public relation and marketing unit and costumes from a medical check-up unit. To strengthen the result of this study, observations and study of secondary data evaluated. The result of this study shows that marketing promotion programs have a target that was not segmented, which all people from every level can enjoy it. PMI Bogor hospital decides to design their media by giving the responsibility to public relation and marketing unit. By media that wearied in four marketing communications unit, that was enough variations in

Corresponding Author:

Dian Surtikanthi

diansurtikanthids@gmail.com

Received: 26 December 2018 Accepted: 23 February 2019 Published: 7 March 2019

Publishing services provided by Knowledge E

(c) Dian Surtikanthi. This article is distributed under the terms of the Creative Commons

Attribution License, which permits unrestricted use and redistribution provided that the original author and source are credited.

Selection and Peer-review under the responsibility of the $2 \mathrm{nd}$ International Meeting of Public Health 2016 Conference Committee.

\section{G OPEN ACCESS} using media which consist of the mouth of mouth communications, customer service, brochures, radio advertising, give vouchers, service packets, talk show, and soon. From the hall of the interview, information got that; customers were not touched too much by media promotions. Although not know much about developments mix, costumes give a positive response to the advertisements that done. But, to make the result of the promotions programs stronger, the writer suggests that public relation and marketing unit keep developing promotions mix that was done before by doing more deep of analyzing and use a different method of marketing promotions.

Keywords: Promotion; marketing; personal communications; advertising; marketing promotion; public relation

\section{Introduction}

Hence fast growth in the health services business and with the rapid increase in medical technology, as well as the high investment costs of the hospital, each hospital trying to improve the utilization of services. Hospitals need to market the services that it offers through a marketing unit. With so hospitals can communicate the services provided, so that later if needed, people can use the facilities at the hospital so that the hospital utilization increases. One way marketing is by the hospital is through the promotion mix. According to Lovelock and Wright (2007), the promotional mixes that can be used by hospitals are personal communication as an example of a story by word of mouth, 
advertising, and sales promotion. Another promotional blend that can also be used by Lovelock and Wright (2007), Kotler (2005), and Lupiyoadi (2001) is a community relation. Although some hospitals already have marketing unit and running a marketing campaign for a long time, not necessarily the promotional activities are undertaken by the wishes of the customer so as not to attract the attention of customers. The might happen in the medical check-up services PMI Bogor Hospital. Since 2008 to 2011 visitors number in medical check-up have been decreased quite a lot as seen in the table as follows:

TABLE 1: Amount of Visitor in Medical Check-up Service in PMI Bogor Hospital 2011.

Year Visit of MCU
2008
2009
2010
2011

The Number of MCU's Visitors in a
Year
1.420
733
831
687

Also, based on product evaluation services performed by the hospital, noted that almost half of customers (46\%) of 48 respondents do not know the medical check-up services. Previous research by Mary in 2006 also mentioned that there are still many consumers who feel that the information supplied by the hospital are still lacking. That's why the research entitled "Analysis of the promotional mix of service medical check-up at the hospital PMI Bogor in 2011" was made.

The purpose of this study was to analyze the stage of preparation of the activities of the promotional mix PMI Bogor Hospital which consists of knowing the target audience, determine the purpose of promotion, designing messages, select the network promotion, marketing promotions compile a total budget, making decisions promotional mix and measure campaign results. Moreover, the purpose of this study was to obtain information about the activities of the promotional mix medical check-up services PMI Bogor Hospital through personal communication, advertising, sales promotion, and public relations.

\section{Methods}

This research was conducted at the Medical Check-up services PMI Bogor Hospital in December 2011-January 2012 with qualitative methods through in-depth interviews, observation, and study of the document. Informants in this study taken purposive based on the principle of conformity and adequacy regulations. As for the characteristics of the informer is as follows. 
TABLE 2: Characteristics of Informants.

\begin{tabular}{|c|c|c|c|c|}
\hline Informant & Name & Occupation & Information & Status \\
\hline 1 & $\begin{array}{l}\text { Yudha } \\
\text { Wahyu }\end{array}$ & $\begin{array}{l}\text { Head of Public Relations and } \\
\text { Marketing Unit }\end{array}$ & $\begin{array}{l}\text { Public Relation and } \\
\text { Marketing Unit }\end{array}$ & Ten years worked \\
\hline 2 & $\begin{array}{l}\text { Citra } \\
\text { Mega }\end{array}$ & $\begin{array}{l}\text { Staff at Public Relation and } \\
\text { Marketing Unit }\end{array}$ & $\begin{array}{l}\text { Public Relation and } \\
\text { Marketing Unit }\end{array}$ & Five years worked \\
\hline 3 & $\begin{array}{l}\text { Firman } \\
\text { Adiyasa }\end{array}$ & $\begin{array}{l}\text { Staff at Public Relation and } \\
\text { Marketing Unit }\end{array}$ & $\begin{array}{l}\text { Public Relation and } \\
\text { Marketing Unit }\end{array}$ & Six years worked \\
\hline 4 & $\begin{array}{l}\text { Ditto } \\
\text { Arief W }\end{array}$ & High School Student in Bogor & Private consumer & Private consumer \\
\hline 5 & $\begin{array}{l}\text { Dewi } \\
\text { Novita }\end{array}$ & Secretary in Jakarta & Consumer companies & $\begin{array}{l}\text { Consumer insurance } \\
\text { company }\end{array}$ \\
\hline
\end{tabular}

A triangulation source is done by obtaining information, facts, and data from different informants. Triangulation method of data collection done by in-depth interviews, observation, and review of secondary data.

\section{Results and Discussion}

Based on the results of in-depth interviews to each informant coupled with observation and review of secondary data, there is an analysis of the promotional mix activities of medical check-up service in PMI Bogor hospital in 2011 which discussed based on the components of variable research on the conceptual framework compared with theories.

\subsection{Preparation phase in promotion mix activities}

Kotler (2005) states that there are at least eight stages in the preparation of an active promotion mix activities, namely:

\subsubsection{Knowing the target audience}

According to Hartono (2010), the audience in the form of their promotions may potentially utilize hospital services, those who are already using, those who decide the necessity of using (deciders), or those who influence others to take advantage of (influencers). This goal can take the form of individual, group, community special, or the general public.

Based on interviews with three informants from the public relations and marketing unit, the medical check-up services have not segmented the target audience. Promotion program that has done is intended for all people. Public relations and marketing unit have realized the importance of determining the target and expect their market 
segmentation, but until now the determination of the target can't be conducted due to the limited workforce.

\subsubsection{Identifying campaign goals}

According to Hartono (2010), there are several stages of promotion purposes where the consumer had to take, namely the awareness, knowledge, attitudes, choices, steadiness, and action. Promotional purposes of medical check-up services at PMI Bogor hospital namely:

1. Awareness. The use of public relations and marketing unit is to tell people who do not know about medical check-up services in PMI Bogor Hospital.

2. Knowledge. This promotion also aims to inform the public about what kind of medical check-up services that they can get in PMI Bogor hospital. As for the next stage which is the stage of attitude, choice, stability and action, public relations and marketing unit not in that direction because of the hospital ethics.

\subsubsection{Designing massages}

According to Lupiyoadi (2001), the ideal message is a message that can give attention, attract, arouse desire, and generate action, which is all known as AIDA method. Based on observations, it can see that the hospital has tried to stimulate consumer desire to use attractive brochure designs. Based on interviews, the hospital has also used quite interesting promotional methods such as radio broadcasts and talk shows. Hartono (2010) states that there are three stages in the determination of a message: message creation, assessment, and selection of words, and the use of the news. In the production of the letter, which is deciding what promotional methods used were the directors of the hospital. However, public relations and marketing section are free to conduct an assessment and selection message.

\subsubsection{Selecting promotion network}

Lovelock and Wright (2007) said that the promotion experts perform the separation into two major parts, namely the promotion mix personal communication and non-personal communication. PMI Bogor Hospital has a network of sale in the form of personal interaction with their service and customer service when working with these companies. 
Non-personal communication done with print and broadcast media such as brochures and radio broadcasts and websites.

\subsubsection{Develop marketing promotions total budget}

Lupiyoadi (2001) states that set the marketing budget are crucial in determining the media to be used. In establishing the promotional budget, public relations and marketing unit have no special allocation. There was no detailed information about how much total funding marketing activities and how the funds allocated for medical check-up services. However, the management granted funding each year for the entire program. Funds allocated according to priorities, where units need promotion first awarded funding.

\subsubsection{Promotion mix decisions}

The decision in choosing the promotional mix what used is taken by the head of public relation and marketing unit with management approval.

\section{Personal communication}

According to Lovelock and Wright (2007), personal communication is communication directly not only in sales but also in customer service and stories from mouth to mouth. This type of promotion is done directly by the hospital's customer service and stories from mouth to mouth - customer service given in the form of customer service to serve customers who require information about the service. And the story of mouth is done either by a hospital employee in spreading the good news about the hospital, as well as by customers who were satisfied with the services provided.

Meanwhile, personal selling, public relations, and marketing unit visited several companies to conduct cooperation contract in the utilization of services. Barriers of promotion activities through personal communication is the need for energy in the form of human resources are genuinely willing to spend some time in this campaign.

\section{Advertising}

Some types of advertising used by hospitals PMI Bogor in accordance with the said Kotler (2005) is a media brochure, directions such as toward the hospital and the course of the room, a sign of the instructions as a sign pointing the place, the promotion of audiovisual through radio broadcasts $\mathrm{RRI}$ and information in the website. The resistance 
of the advertising brochure type distribution is lacking. The relates to the cost of printing brochures are relatively large and the cost to hire for distribution.

\section{Sales promotion}

Purnama and Lingga (2002) say that there are three distinct benefits of sales promotion tools, namely communication, incentive, an invitation. Sales promotion is done by giving packets of services whose purpose is to contact. Another sales promotion done is the provision of free service vouchers and health broadcast on radio station RRI. The aim of this promotional activity is an incentive and invitation. Barriers to sales promotion activities are the people who like to compare prices with other hospitals and the perception that people are afraid to do a medical check-up for fear of getting caught the disease. The result is that none of the radio listeners who get a voucher for free medical check-up services take advantage of the coupon.

\section{Public relations}

Public relations activities that can be done by marketing services according to Kotler (2005) is a hardware interview, speeches, seminars, annual reports, charity events, sponsorship, publicity and community relations. Public relations conducted by the hospital PMI Bogor is a seminar or talk to a layperson, accompanied by the distribution of brochures and answering questions about medical check-up. Moreover, it also conducted a charity event with the conduct of mass treatment in collaboration with other hospitals as well as the publication of medical articles. Barriers of public relations are that if the hospitals are not thorough in preparation for example in the selection of a seminar promotion method can result in fewer participants coming.

\subsubsection{Measuring success in promotion development plan}

During this time, the means used to measure the success of these promotional activities is to look at the number of patient visits. When viewed that the number of visits increases, the increase in utility service use has reached and that means promotion done has achieved the goal.

As for the future development plan, each informant had each plan. The first informant is planning to develop a media campaign through word of mouth stories developed 
into the target communities. While the second informant preferred to increase the cooperation with subscription companies. The third informant has plans to build a media campaign through newspapers and radio.

\subsubsection{Measuring results promotions}

After carrying out promotion in medical check-up service, according to Lupiyoadi (2001), companies must measure their impact on the target audience, whether they know or remember the messages given. Based on the interview of two informants who came from private consumers and consumer companies, obtained information that one of the informants had previously seen a media campaign to brochures. While the other informant claimed that he has never seen a media campaign. While based on the questionnaire product evaluation services performed by the hospital itself obtained the information that many customers do not yet have information about the services of medical checkup.

Information to remembered by the informant regarding the brochure has also been entirely satisfactory where the information which he mentioned contained in the booklet. The informant who claimed to have seen the catalog says that the design is good, but it should add the information of price.

Based on the interview can be seen that the response of the two informants against promotion mix selected by PMI Bogor Hospital has been positive. Where the two informants said that the promotion of the brochure is essential, to provide information to people who do not know about the medical check-up services PMI Bogor Hospital. This type of development through word of mouth communication also has a considerable influence given one of the informants to get information first from her family members.

Regarding sales promotion package is selected, the two informants have their reasons. One informant claimed to use advance package for academic purposes. While the other informant claimed to get a medical check-up service type $A$, where the examination did is a complete examination. The reason is by the sum insured under the insurance agreement where he worked.

\section{Conclusions}

In general, promotional activities in medical check-up service at the hospital PMI Bogor is good enough because it has developed a media campaign started personal and nonpersonal communication. However, there are still less effective promotions such as radio 
broadcasts and giving vouchers to the listener who gives the question because no one had come to the hospital.

Promotional activities conducted through personal communication is good enough, namely through the story of customer service and word of mouth. Advertising activities were done through flyers; radio talk shows in the form of better health through radio station RRI and media marketing website. Directions hospitals and indoor, indoor directional signs, symbols and logos, as well as the hospital, have also been available in hospitals PMI Bogor.

The promotion of sales made through the sales package of services available. It also uses media contest to give vouchers for RRI radio listeners are on questions about the health and held a health seminar Public relation activities conducted through seminars or talk to the layman, the charity event of mass treatment in collaboration with other hospitals as well as the publication of medical articles.

Indicators promotion program can see from the number of visits, but there many factors that determine the volume of sales of services, including quality of service provided by all service personnel medical check-up.

\section{Recommendations}

1. It expected that in analyzing the media plan used, public relation and marketing unit is sure in advance that the method will succeed. The can be done by the previous conduct public relation and marketing unit research on consumers.

2. Develop promotional stories through word of mouth to be closer to the communities that have the potential as a community whose members already have a mature age.

3. More attention to the allocation of budget funds for the promotion of medical checkup services.

4. It develops promotion by making a cooperative approach to companies that want to check the health of their employees.

5. I am trying to develop the sale of certain payments by credit card.

6. Make use of existing hospital services such as television to promote medical checkup. And provide customers SMS facility, where customers can ask for information about hospital services. 


\section{References}

[1] Hartono B. 2010. Manajemen Pemasaran untuk Rumah Sakit. Jakarta: PT Rineka Cipta.

[2] Kotler P.1997. Manajemen Pemasaran: Analisis, Perencanaan, Implementasi dan Control. Jakarta: Prenhallindo.

[3] Lovelock and Wright.2007. Manajemen Pemasaran Jasa. Jakarta: PT Indeks.

[4] Lupiyoadi R. 2001. Manajemen Pemasaran Jasa : Teori dan Praktik. Jakarta: PT Salemba Emban Patrial.

[5] Purnama, C. M. Lingga. 2002. Strategic Marketing Plan. Penerbit Gramedia: Jakarta.

[6] RS PMI Bogor. 2011. Company Profile. Bogor: RS PMI Bogor. 